\title{
FRENCH ORIGINS \\ OF ENGLISH TRAGEDY
}

\section{Richard Hillman}

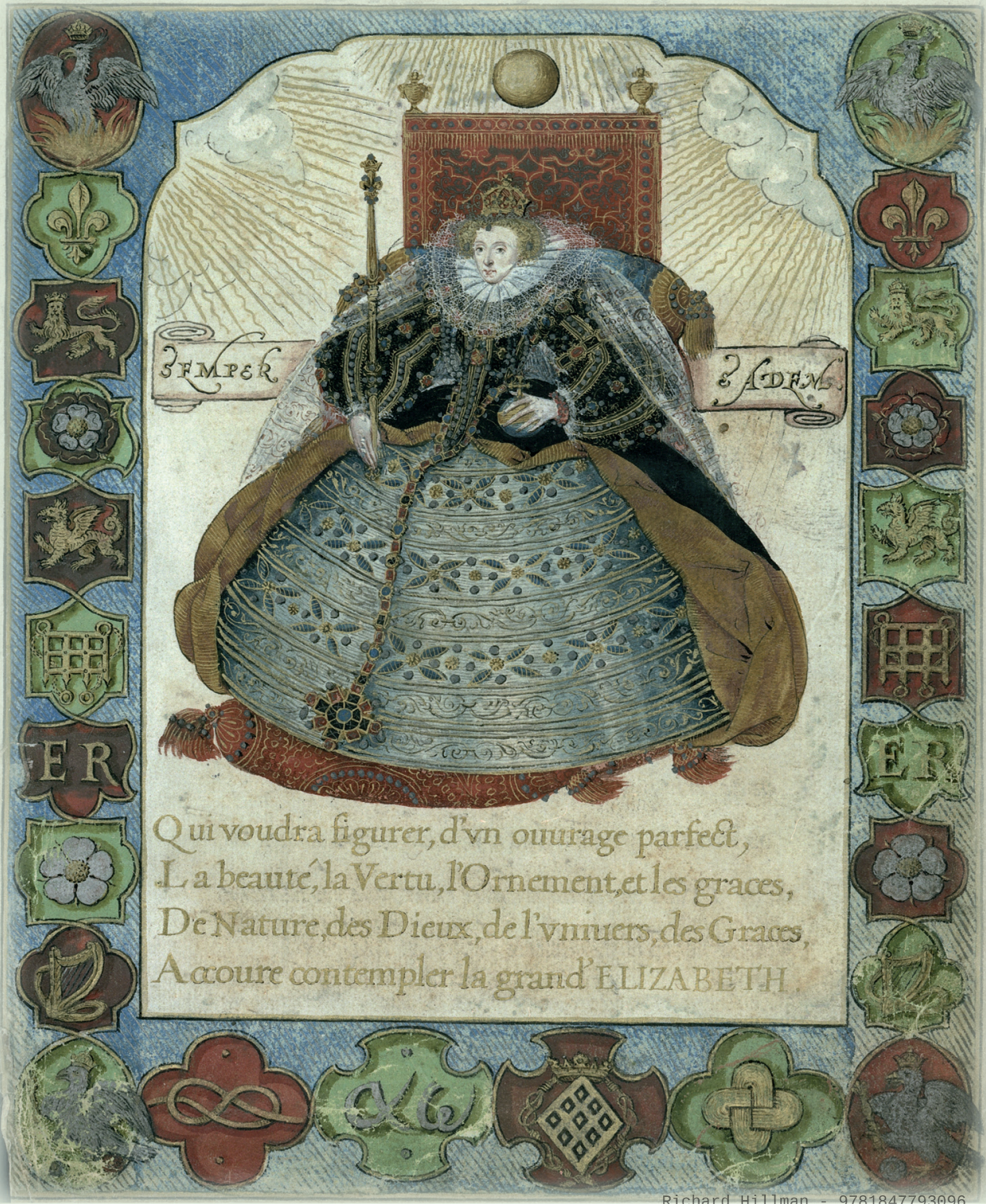




\section{French origins of English tragedy}

\section{MANCHESTER 1824}

Manchester University Press 
Richard Hillman - 9781847793096

Downloaded from manchesterhive.com at 04/26/2023 12:09:25PM 


\title{
French origins of English tragedy
}

\author{
Richard Hillman
}

Manchester University Press

Manchester 
Copyright (C) Richard Hillman 2010

The right of Richard Hillman to be identified as the author of this work has been asserted by him in accordance with the Copyright, Designs and Patents Act 1988.

Published by Manchester University Press Altrincham Street, Manchester M1 7JA, UK www.manchesteruniversitypress.co.uk

British Library Cataloguing-in-Publication Data is available Library of Congress Cataloging-in-Publication Data is available ISBN 9780719088476 paperback

First published by Manchester University Press in hardback 2010

The publisher has no responsibility for the persistence or accuracy of URLs for any external or third-party internet websites referred to in this book, and does not guarantee that any content on such websites is, or will remain, accurate or appropriate. 